University of Louisville

ThinkIR: The University of Louisville's Institutional Repository

Electronic Theses and Dissertations

$5-1922$

\title{
Linseed oil and its oxidation products.
}

Mary Louise Towles

University of Louisville

Follow this and additional works at: https://ir.library.louisville.edu/etd

\section{Recommended Citation}

Towles, Mary Louise, "Linseed oil and its oxidation products." (1922). Electronic Theses and Dissertations. Paper 1451.

https://doi.org/10.18297/etd/1451

This Master's Thesis is brought to you for free and open access by ThinkIR: The University of Louisville's Institutional Repository. It has been accepted for inclusion in Electronic Theses and Dissertations by an authorized administrator of ThinkIR: The University of Louisville's Institutional Repository. This title appears here courtesy of the author, who has retained all other copyrights. For more information, please contact thinkir@louisville.edu. 
University of Louisville

Linseed 0 iI

and its

Oxidation Products

\author{
A Dissertation \\ Submitted to the Faculty \\ Of the Graduate School of Arts and Sciences \\ In Partial Fulfillment of the \\ Requirements for the Degree \\ of Master of Science
}

Department of Chemistry

By

Mary Louise Towles

1922 
Linseed oil is the oil from the plant linum usitatissimum. It is not a new oil, for we read that the Greeks and Romans used it, not as it is used today, but as a food, and it is still used for that purpose in some countries, especially in Russia, Poland, and Hungary.

The ofl was first introduced into the United States during the ninetoenth century, and in 1810 there were two hundred elghty three linseed oil mills in only fourteen states. In those days the process of obtaining the oil from the seed was tedious, and the yield was poor, for the oil was extracted by means of the old-fashioned mill stones. After the demand for linseed ofl increased, ofl had to be imported fr om foreign fields. Up until 1861 the putput was one million gallons per year. Prior to that time the largest portion of the seed was grown and used only for the fiber, with the seed regarded as a by-product, but now the fiber itself is only a by-product, and the plant is grown for the seed. After 1865 the production of flax moved west from the middle states, where all of the yield of the United States had been grown. The demand increased greatly from year to year. In 1870 the industry recelved a great stimulus when the old mill stones used 
for pressing were replaced by rolls, and in ten years the yearly crop was quadrupled. All the seed is now grown west of the Alloghanies, and the states in the east st1ll send to India and Russia for seed.

Linsced is flat and oval in shape, with a slightly unpleasant odor. It contains 25 per cent albumin, 8 per cont water, $28-40$ per cont oil. Then the oil is expressed instead of extracted with a solvent the per cent of oil is $8-15$ per cont less. The yield of oil also varies with the country from which the oll is imported. Russian oil gives 32-38 per cent o1l, North American seed 36-38 per cent, Morocco 36-40 por cent, China 31-38 per cent. One bushel of seed gives about two and one half gallons of oil,.. by expression. The age of the seed also influences the yield of oil. As a rules seeds from two to six months old give botter yield than fresh seed.

Before the seed is pressed it is always stored, for it is found that the oil is less turbid and also less viscous if the seed has been stored for some time before expression. Great caro must be taken in the storage of linseed. It doteriorates rapidly from moisture and often perishes entirely. To prevent this the seods must be stirred and turned frequently. 
They are kept in dry, cool, well ventilated rooms, and the piles of seeds are often turned completely over to keep them from mould or decay.

The seed, as it comes from the exporters, is always full of Impurities-not only dust and chaff but also other seeds which may become mixed with the linsoed, such as rape seed, mustard seed, also sand and earth. The chaff and dust can be removed by exhaust fans. Then the seed is put on an oscillating screon. The seeds drop through and leave the coarse impurities behind.

Before the oil can be extracted the colls or particles which hold the oil must be broken up. So heavy rolls are used to crush the seed. Often when the seed is unusually dry a small amount of water is added to make a homogeneous mass. The machinery in use today is a series of rolls, four in number, arranged one above the other. The seed is fed in between the two top rolls, ard is then worked down between the second and third rolls. The welght of each rolil rests on those below 1t, so that when the seed is between the third and fourth rolls it has the pressure of all three rolls upon 1t. In this way it becomes crushed 
to a very fine meal:

The meal may be expressed cold, or it may be heated. A great deal of it is heated so as to make the oil run more smoothly. If moisture is also present the heat and molsture combined help break the cell wails, and loosen the gelatinous coating which covers the outside of the cells. The heat also tends to coagulate some of the albuninous material dissolved in the oil.

The oil was formerly heated over an open fire in an iron pan, or with hot water, but the danger of overheting was very great. The result was always a burnt oil or one with a strong odor, or a dark color. Today the meal is heated in a steamjacket-kottle, with the temperature carefully regulated.

Cold pressed oil makes a much bettor grade of oil than hot pressed oil. The color is lighter, but the yield is not quite so large, since the oil does not flow so easily, and for this reason the greater the per cent of oil is expressed hot. Cold pressed oil is used more for edible purposes than for the paint industry.

There are three general methods for obtaining the oil from the seed-rendering, extraction with a 
solvent, and expression.

Rendering is the oldest method. It was used centuries ago by the natives of West Africa and other uncivilized countries in obtaining crude oil from the seeds. The meal was either heated over an open fire in a kettle, or was bolled with water and the olly layer run off. But this method seemed to change the constitution of the oil, and allowed many impurities to flow into the oil, and this process is never used today.

The extraction with a solvent is used extensive1y. The method as given by Ennis, is as follows:

The seed is not ground so fine as for expression with bydraulic press. It is then heated to $180^{\circ}$ to drive off moisture. The meal is put into a percolator. The solvent(naphtha) is passed through a coll, with steam in the shell, to increase its solvent power. The naphtha then drops in on top of the coarse meal. It percolates through the meal and the solution of oil in the solvent is drained off at the bottom of the tank. This solution passos through the tubes surrounded by steam. This boils off the naphtha, whith goes to the condenser to be used again, and the oil goes to a container. This process is carried 
on for three days, for at the end of that time the greater part of the oil is extracted. The oil in the tank is then raised to high temperature to drive off any remaining naphtha.

The first extraction was carried out by Jesse Fisher, in 1843. He used carbon disulphide as a solvent, but the oil which he obtained had the odor of carbon disulphide, traces of sulphur were found precipitated in the oil, and the meal left behind was unfit for food.

Carbon tetrachloride has been used with some success as a solvent, as it has no unpleasant odor, is not poisonous, leaves no residue, has a low boiling point, and is not inflammable.

The first solvent was carbon disulihide, now in aisuse, and the principal solvents used today are benzene, petroleum ether, ether, carbon tetrachloride, acetone, and recently liquid sulphur dioxide has been used with some succoss.

The solvent used must have certain characteristics. It must dissolve only the fatty portion of the oil, not the gum and mucilage. The solvent must be removed completely by distillation , so as to be entirely recovered, and must give no flavor to the oila 


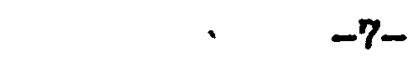

There is some objection to extracting by means of a solvent. The meal left is no good for cattlo food $_{3}$ It contains only 2-3 per cent of oil left after extraction process is complete, and the husks are not fit for food. Another trouble is the high cost of steam for the process. All these difficulties have not made the process the most popular one. In fact, today, very little oll is expressed by this method.

The best mothod for extracting the ofl is by expression. The method was in use thousands of years ago, in a very crude way, but modern methods date from 1795, when Joseph Bramah Invented the hydraulic press. The pressure is applied very slowly at first, and is gradually raised up to two tons per square inch. The cakes are collected, given a second heating, and pressed again.

The cake left from expression is very valuable as a cattlo food. It is not used to any large extent in the United States, but is used extensive$1 \mathrm{y}$ in the European countries, and all Iinseed cake made in the United States is shipped abroad. It is considered a valuable by-product of the linseed oil Industry, often bringing from $\$ 18$ to $\$ 25$ per ton. The average composition is: $s$ 


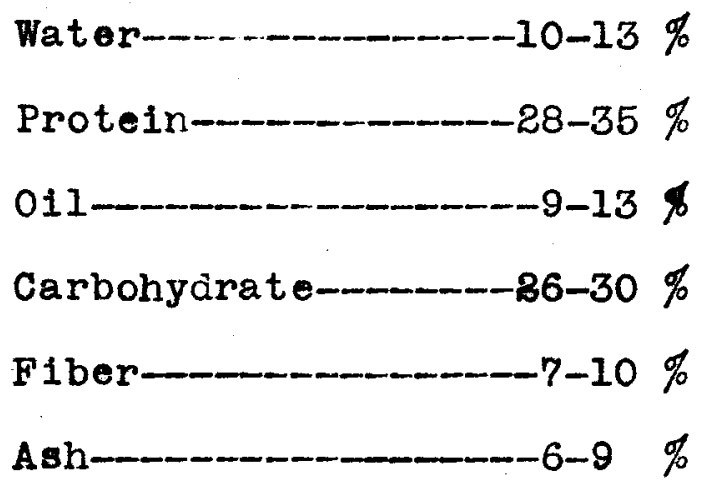

The impurities found in linseed oil are of a varied nature, depending on the method of expression. Even if it is extracted by means of a solvent, different solvents dissolve out different materials, and different impurities come out at different temperatures.

Both organic and inorganic substancos are dissolved in the oil. Of the inorganic impurities water and metaliic salts are the most important. The water is easily removed when, during the refining process, the oil is heated to a high temperature. The mineral salts aro usually precipitated and settle to the bottom of the tank during the reIining process.

The organic impurities aro not so easy to remove. These consist of protein, carbohydrates, gums, resine, enzymes, soaps, glycerin, lecithin, and the higher hydrocarbons. All of these excopt the proteins are present in very small quantities, 
so that their presence does not seriously effect the 011. They are removed with the precipitation of the protein.

The protein material comes from the cells of the plant, and is dissolved in the oll. These proteins are soluble in water, and in dilute salt solution. Thoy cause emulstions in the oil and form persistent omulstions when the oil is shaken with water. The oil is cleared of this protein material by adding salt solution or mineral acid. These precipitate the protein, and it settles to the bottom of the tank, carrying with it any other dissolved material. Filtration of the oll removes some of the impurities, that is, those held in suspension, but the proteins and the vegetable or an 1mal gums are colloidal and cannot be filtered out. Other oils are often present in linseed 011, due to the impurity of the seed before the oil is expressed. 011 of mustard seod is the commonest impurity. If this oil is present in large quantities the linseed loses its property of drying rapidiy. The refining of linseed oil can be done by numberloss processes, in fact, the processes are too many and various to be enumerated here. The matn 
types of processes will be disoussed briefly. More filtration, after the oil has been allowed to settle, and the olear liquid dram off, is often used for purification, and fives a vory bright alear oil, which is quite satisfactory for ordinary paint work. The oll is often tanked to clarify it. It is put into large open tanks and kept at a temperature of 150 degrees, Centigrade. During the process air is blown through the ofl by fans or blowing machines. This procoss givos a splendid cloar oil, with no broak on hoating, but it is very slow and often chemical means of purification are resorted to 4

Various types of chemicals are used in refining linseed oil. Alkaline solutions were once used in purifying, but today they have been replaced by other agents, because they saponify with the oil and form emulsions which are very persistent. Aclds are used extensively, as well as zinc chloride. Certain solids, such as magnesia, Fuller's earth, powdered minerals are used, which by mechanical means carry down suspended materials and impurities in colloidal solution.

Wasl found a satis tory method of refining 
with sulphuric acid. Conoentrated acid is added in a thin stream, one part acid to four hundred parts of oil. When this is thoroughly mixed, bolling water is added. The mixture is then allowed to stand and settle, the oil is drawn off, and three per cent dry sodium chloride is added. This takes out the water and settles to the bottom of the tank. The oil is then filtered through saiks of wheat bran.

Engleduc has a method of refining by means of ozone. The molsture is all removed from the oil and no heating is necessary to destroy the color of the oil.

The 'wet process' consists of passing steam through a mixture of Iinseed oil and hot water from ohe to two hours. This mixture is allowed to stand, and after several days it is found that the impurities form a white layer between the oll and the water layers. The oil is then drawn off from the water and is heated to 220 degrees to drive off any remaining water. Sometimes Fuller's earth or lead sulphate is adde to bring down any colloldal matter or any coloring material. In Nordlinger's process the organic fatty 
acid sajts of the heavy metals are dissolved in ten to twenty parts of vegetable or rosin 011. This solution, called refining oil, is added to the linseed oll. The oll seems to go into solution, but if It is allowed to stand a turbidity is soon noticed. The salts of the heevy metals are thrown out of solution and as they settle to the bottom of the tank the impurities are carried with them.

When linseed oil is allowed to stand a thick mucilaginous mixture setties to the bottom of the tank. This has been studied, but today the chemical character of the 'foots', as this sediment is called, technically, is not known. Elsenschyml 7 has been doing some work on linseed foots and gives the follofing analysis.

$$
\begin{array}{lr}
011 \text { and insoluble portion } & 75.8 \% \\
\mathrm{SiO}_{3} & \text { none } \\
\mathrm{CaO} & 3.26 \% \\
\mathrm{MgO} & 4.99 \% \\
\mathrm{~K}_{2} \mathrm{O} & 10.27 \% \\
\mathrm{P}_{8} \mathrm{O}_{5} & -1.08 \% \\
\text { Total } & 99.60 \% \\
\text { The color of linseed oil is usually a pale }
\end{array}
$$


source of the oil, the extraction process used, and the refining process. But the requirements of the trade are becoming greater and greater with respedt to the color of linseed oil. The reason offered is that they must have an oil which is absolutely colorless with white pigments, but when linseed oil is dried it is bleached absolutely colorless. On the other hand, I inseed oil which has not been changed by bleaching agents is much more pure and harmless to pigments than bleached oil.

The principal bleaching agents emplgyed today are sodium peroxide, hydrogen peroxide, chlorine, calcium chloride, potassium permanganate, potassium dichromate; ozone, sulphurous acid, and sodium thiosulphate.

Bleaching with light is really the best method of bleaching, for in this way the oil is not changed materlally. The only change is trat the oll becomes somewhat thickened and slightly rancid, but the main objection to the method is the length of time which the process requires. The oil must be stored for several months before any bleaching takes place. Today the oil is placed in shallow tanks and exposed to the direct sunlight. If the rays of the sun can penetrate through 
the whole depth of the oll the process can be completed in a much shorter length of time, usually in four to five weoks. The rays of the sum have the bleaching effect, and if the oil is kept in a dark place or in deep tanks the same process would take months. In case ozone is used instead of air, the process takes but four to five days. The oil is bleached by aspirating the ozone through the oil. The basis of the action of the chemical agents is the action of the chlorine or the oxygen. In the case of the ozidizing agents, sulphuric acid or hydrochloric acid is added to froe the ozygen or chlorine. With potassium dichromate the oil is bleached according to the following equations:

$$
\begin{aligned}
\mathrm{K}_{8} \mathrm{Cr}_{8} \mathrm{O}_{7}+5 \mathrm{H}_{3} \mathrm{SO}_{4} & =\mathrm{Cr}_{3}\left(\mathrm{SO}_{4}\right)_{3}+2 \mathrm{KHSO}_{4}+4 \mathrm{H}_{3} \mathrm{O} \\
\mathrm{K}_{3} \mathrm{Cr}_{2} \mathrm{O}_{7}+14 \mathrm{HCl} & =\mathrm{Cr}_{3} \mathrm{Cl}_{6}+2 \mathrm{KCl}+7 \mathrm{H}_{3} \mathrm{O}+6 \mathrm{Cl}
\end{aligned}
$$

Only a small per cent of acid or oxidizing agent has to be added to get the desired effect, but even that swall amount injured the oil.

Oil is often bleached with Fuller's earth, which consists chlefly of silica, alumina, iron, and Iime. This is added to the oll in a very mall quantity and mixed with the oll for three to four hours, and kept at a temperature of 200 degrees. This process 
is more or less mechanical, the Fuller's earth taking up any suspended material, and is not dependent on any chemical action.

Bolled oll formerly meant what its name 1mpl-ied--oll which had been boiled or heated to a high temperature, to rid it of impurities, and which had drier added to it. Today boiled oil is often not heated at all, but merely has diler added, though some of the manufacturers do heat the oil to a more or less high temperature before adding the drier. Litharge is the most common drier used today, although some concerns prefer the manganese and lead resinates, Ilthr ge cannot be added in excess of one per cent. This much makes the oil dry and hard in five hours, if it is spread in thin layers.

Oil to which drier has been added dries in much less time than ordinary commercial refined linseed o1l. This is not thought to be due to the addition of oxygen to the oil itself, but to the substances which are added which absorb oxygen from the air themselves and then transfer it to the o1l, as shown by the following equations: 


$$
\begin{aligned}
3 \mathrm{PbO}+0 & =\mathrm{Pb}_{3} \mathrm{O}_{4} \\
\mathrm{~Pb}_{3} \mathrm{O}_{4}+011= & =(011+0)+3 \mathrm{PbO}
\end{aligned}
$$

In making boiled oil the oil was once heated over an open flame to a high temperature, but this process makes the oil much darker. The oil begins to decompese, gets too thick, and the fumes cause great loss. The temperature to which the o1l is heated has much to do with the drying power of the oil. Most of the oil is heated to 270 degrees, for the varnish trade requires an oil which does not break at 270-280 degrees--that is, shows no coagulation or soild material dropping out at that temperature ${ }_{8}$. The drier is added while the oil is hot and then the mixture is allowed to settle for four or five days. Another process is to heat the oil to 125-130 degrees by means of super-heated steac but this latter process has not come into common use. Boiled oll has altered properties from raw oil. In the settling process the oil becories lightee in color and somewhat thickened. This latter property is especially true of manganese dried oil, while lead dried oil always deposits foots. In consistency bolled oil should be only slightly more viscous than raw oil. The temperature must be watiohed carefully, 
as this greatly influences the viscosity of the oil. In color boiled oil varies from pale yellow to a reddish brown, depending on the method of bolling and the drier used. A dark color is usually a good indication of a too high temperature, Manganese driers give pale oil while lttharge and red lead give a dark oll. Bolling by means of super heated steam also gives a pale ofl. The trade requires a clear transparent oil and this is procured only by letting the oil stand.

The requirements as to length of time for drying vary with different docalities or different purposes to which the oil is to be put. It can be made to dry in so short a time as five to six hours, but the usual length of time is eighteen to twentyfour hours.

Blown oil is made by blowing superheated steam through the oil at a temperature of 450 degrees. The breakable part of the ofl is then decomposed and passes off as vapor. There is also a sediment of insoluble impurity which as a rule consists of mucilage and protein which settles to the bottom of the tank on cooling. This oil is then centrifuged to separate out solid material and then treated with 
Fuller'd earth to lighten the color. The oil is then filtered and cooled to 16 degrees belor zero. The solid stearin separates out at this temperature and after filtration the oll is ready for the market. This oil is very highly rofined and very pure. It is used principally in varnish making.

Stand oll is a very heavy viscous form of linseed 011, used principally in making enamel and linoleum. The oil probably originated in Holland, where linoleum was first made. The oil is heated to 550 degrees Fahrenhelt, care being taken that the oll is sufficiently refined not to show any break at that temperature. The oil is kept at 550 degrees until it becomes heavy and viscous. The specific gravity changes from 0.93 to 0.98 . At this point a small quantity placed on a plece of glass and allowed to cool 'piles' or stands up in a mound and runs very slowly. A small amount of drier, usually Iitharge, is added while the oil is at 550 degrees and the oil is then allowed to cool gradually. More than 0.1 per cent of drier is never used, since the pbject of the process is to keep the light color of the oll, and more drier would tend to darken the oil. Cobalt is the best drier in use today. In this process 
it is thought that the oil polymerizes, for it always thickens, and upon analysis it is found that the molecular weight becomes either double or triple what it was in the original oil. Fahrion found that if he heated linseed oil to a high temperature a substance of mlecular wight approximating 2000 was found. Linseed oil is liable to adulteration in various ways, depending on the price of the oil as well as of the adulterants. The inost probable adulterants ase drying oils, such as candle nut oll, safflower o1l, sunflower oil, and soya bean oll, hydrocarbons, cottonseed oil, nigerseed oil, tung oll, flsh oil, hempseed oil, rape oll, mineral olls, rosin and rosin o1ls.

Fish. oils can often be detected by odor, especially by rubbing the oil between the hand. Another test for fish oil is the phytosterol acetate test, or Morrell's testio

Rosin oil can be detected by the sulphuric acid color test. Pure oll gives a dark brown clot, whil adulterated 011 gives a red clot. The unsaponifiable number gives a reliable test, Rapeseed oll can be detected by the jelly-like mass formed on heating the oil to 300 degrees. Cottonseed oil is

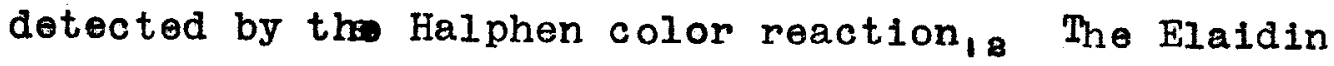


test is often used for the purity of o11. A great per cent of non-drying oil gives a solid mass with $\mathrm{HNO}_{8}$ (nitrous acid) while a great per cent of drying oil gives a liquid product: with nitrous acid 13 Of course, all the adulterants seriously effect the drying of the oil. Mixed wh rosins the oil dries but it dries soft and soon perishes, on account of this softness. With mineral oil present the oil dries but the mineral oil separates out and rises to the surface of the film. Fish oll does not dry at all.

Adulterations have a noticeable effect on all of the characteristics of Inseed oil. The specific gravity is often not changed, for by adding some of an oll of higher specific gravity and some of lower specific gravity the final result would not be changed even with great adulteration.

The film test is often used for detection of adulteration, the extent of drying varying in proportion to the amount of adulteration. The insoluble bromide value is an important test for purity, for the most of the adulterants used give no insoluble bromides. 14

The American Soclety for Testing Materials 
gives the following specifications for linseed of 15

Raw 011

Specific Gravity, $\frac{15}{15} . \frac{5}{5}$

Spocific Gravity, 25

Acid number

Saponification number

Unsaponiflable matter, percent

Refractive Index

Iodine number, Hanus

Boiled_e1l

Spocific Gravity, $\frac{15}{15} . \frac{5}{5}$

Acid number

Saponification number

Unsaponiflable metter, percent

Refractive Index

Iodine number, Hanus

Ash, percent

Manganese, per cent

Calclum, per cent

Lead, per cent
Maximum Minimum
0.936
0.932
0.931
0.927

6.00

195.00

189.00

$\begin{array}{cc}1.50 & - \\ 1.4805 & 1.4790 \\ & 180.00\end{array}$

0.945

0.937

8.00

195.00

189.00

1.5

1.484

1.479

178.00

0.7

0.2

The methods of tests, as recommended by the American Society for Testing Materials are as follows :

General-"Should be made on bil which has been fil- 
tered through paper in laboratory at 60-80 degrees Fahrenheit immediately before weighing out." Specific_Gravity-use pyknometer, capacity 25 cubic centimeters. Make test at 15.5 or 25.5 degrees Centigrade.

Acid_Nuher-method given in Holley. Express in mill1grams of potassium hydroxide per gram of oflis Sapenificat1on_Number-Expressed as with acid'number,7 Insapeniflable_matter=Boemer's method 18 Refractive_Index-use Abbe Refractometer, at 25 degrees Centigrade.

Iodine Number-use Hanus method 19

The elementary composition of linseed oil varies with the method of extraction from the seed. Carbon Hydrogen Oxygen

$\begin{array}{llll}\text { Cold drawn } & 78.11 & 10.96 & 10.93\end{array}$

$\begin{array}{llll}\text { Hot drawn } & 75.27 & 10.98 & 13.85\end{array}$

The oll is thought to contain from ten to thirteen per cent solid fatty acids, that is, stearic, palmitic, and myristic, and elghty-eight to flnety per cent liquid fatty acid glycerides 20 Hazuza and Grüssnera, give the following composition Oleic acid $\quad 5 \%$ Inoleic acid $15 \%$ linolenic acid $15 \%$ 1so-linolenic" $65 \%$ 
Fahrion gives the following composition: solid fatty acids $8.5 \%$ Inolic acid $30.0 \%$ oleic acid $\quad 17.5 \% \quad$ linolenic acid $38.0 \%$

Linseed oil solidifies at 27 degrees below zero, but this varies with the amount of free fatty acids present. At 25 degrees blow zero stearin crystallizes out. Linseed oil flashes at 450-500 degrees. It is soluble in acetone, petroleum ether, ehtyl ether, carbon disulphide, chloroform, carbon tetrachloride, turpentine, benzene, and petroleum, and moderately soluble in alcohol. The oil is given its yellowish color by the green chlorophyll and red erythrophyll and xanthrophyll dissolved in the oil from the seed. The bleaching of linseed oil is dependent upon the changing of this coloring matter into the pale yellow type of chlorophyll.

Linseed oil contains various solid fatty acids, such as palmitic, myristic, butyric, valerianic, and caproic acid glycerides.

Myristic acid, $\mathrm{C}_{13} \mathrm{H}_{87} \mathrm{COOH}$, was found by Mulder, but later investigators 23,33 doubt its existence in Iinseed oll.

Palmitic acid, $\mathrm{C}_{1} \mathrm{H}_{3}, \mathrm{COOH}$, was found by Schuler 34 and later conftrmed by Mulder and others, 38 
Stearic acid, $\mathrm{C}_{17} \mathrm{H}_{35} \mathrm{COOH}$, was first shown to be present by Unverdorben 84 Mulder did not find it, but later workers didis

Arachidic acid, $\mathrm{C}_{19} \mathrm{H}_{39} \mathrm{COOH}$, was found to be present as arachin in linseed oil. Haller found arachidic acid ${ }_{35}$ and it was early worked on by other chemistsan

The unsaturated fatty acids-present are of three types-those with one double bond, those with two, and those with three double bonds.

The principal acid with one double bond of the type formula $\mathrm{C}_{\mathrm{n}} \mathrm{H}_{2 \mathrm{n}-1} \mathrm{COOH}$ is oleic acid. This acld on oxidation in alkaline solution with potassium permanganate gives di-hydroxy-stearic acid, formula $\mathrm{CH}_{3}\left(\mathrm{CH}_{3}\right)_{7} \mathrm{CH}=\mathrm{CH}\left(\mathrm{CH}_{3}\right)_{7} \mathrm{COOH}==\mathrm{CH}_{3}\left(\mathrm{CH}_{3}\right)_{7} \mathrm{CH}_{\mathrm{H}}-\mathrm{CH}\left(\mathrm{CH}_{2}\right)_{7} \mathrm{COOH}$ The acid may be removed from linseed oil by precipitating it as its lead salt. The lead salts of the unsaturated acids are soluble in ether, whlle the salts of the saturated aclds are insoluble. This acid has one ethylene linkage, that is, one double bond of the type $R C=G R, R$ representing saturated radicles.

Oleic acid is a colorless acid, with no effect on litmus. On exposure to air and sunlight 
it turns yellow. After sometime it becomes rancid and forms decomposition products, consisting mainly of formic, azelaic, and di-hydroxy stearic acids, 28,29 When oleic acid is heated with hydriodic acid and phosphorus stearic acid results 30

The presence of only one double bond in oleic acid is proved by its power to absorb only two atoms of bromine or lodine, giving di-brom of diiodo stearic acids, Also, its oxidation with alkaline permanganate giveing di-hydroxy stearic acid proves this formula. Hazura was the first to make the rule that unsaturated acids absorb as many hydroxyl groups as they possess free valency, giving hydroxy acids of same number of carbon atoms as the original acids 38 Therefore, knowing stearic acid to be $\mathrm{C}_{17} \mathrm{H}_{38} \mathrm{COOH}, \mathrm{C}_{17} \mathrm{H}_{33} \mathrm{Br}_{2} \mathrm{COOH}$, or $\mathrm{C}_{17} \mathrm{H}_{33}(\mathrm{OH})_{2} \mathrm{COOH}$,

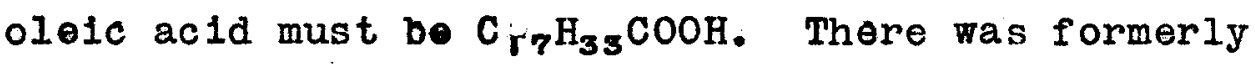
some discussion as to the place of the double linkage in the molecule. The old formula was $\mathrm{CH}_{3}\left(\mathrm{CH}_{3}\right)_{14}$ $\mathrm{CHCHCOOH}_{3}$ but Baruch established the following formula, $\mathrm{CH}_{3}\left(\mathrm{CH}_{8}\right)_{7} \mathrm{CH}=\mathrm{CH}\left(\mathrm{CH}_{8}\right)_{7} \mathrm{COOH}$, which is now the accepted formula.

0lelc acid is present in linseed oll as its tri-glyceride. Nitrous acid changes it to its 1someride elaidin, the triglyceride of elaidic acid, 
which is isomeric with oleic acid.

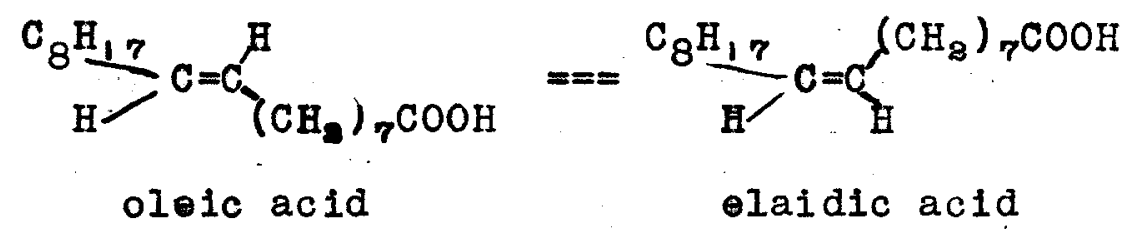

Linolic acid is a member of the unsaturated series $\mathrm{C}_{\mathrm{n}} \mathrm{H}_{2 \mathrm{n}-3} \mathrm{COOH}$, with two double bonds. It composes about fifteen per cent of linseed oil. This acid was thought by Mulder to be the same as linolenic, and he called the mixture linoleic acid. Hazura first found that linolein was a mixture of linolin and linolenin, the glycerides of linolic and linolenIc acids, respectrely.

Linolic acid gives a tetrabrom derivative $\mathrm{C}_{17} \mathrm{H}_{3}, \mathrm{Br}_{4} \mathrm{COOH}$ s4 absorbs oxygen from the air, and forms a solid resinous body. With hydriodic acid and phosphorus it gives stearic acidis on oxidation wth alkaline permanganate it goes to tetra hydroxystearic ac1d, or sativic acid, $\mathrm{C}_{1}{ }_{7} \mathrm{H}_{3}(\mathrm{OH})_{4} \mathrm{COOH} 86$ Goldsobel was the first to establish`the famula for Iinolic acid. He worked on the oxidation of sativic acid and got azelaic, oxalic, and hexoic or caproic actis. This he could explain if he assumed the following formula for the acid: $\mathrm{CH}_{9}\left(\mathrm{CH}_{8}\right)_{4} \mathrm{CH}=\mathrm{CHCH} \mathrm{CH}_{3} \mathrm{CH}\left(\mathrm{CH}_{3}\right)_{7} \mathrm{COOH}==\mathrm{CH}_{3}\left(\mathrm{CH}_{2}\right)_{4} \mathrm{COOH}$ Inolic acid hexolc acid

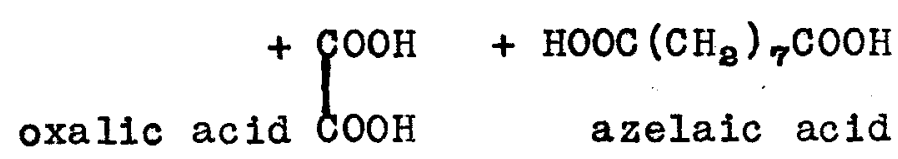


This formula has recently been conflrmed by optical $\operatorname{methods}_{3} 7$

Some evidence has been given as to the possible presence of two stereo-isomertdes of linolic acid in linseed o1l, but the question is still being debated $_{38}$

Linolenic acid, $\mathrm{C}_{17} \mathrm{H}_{29} \mathrm{COOH}$, belongs to the series $\mathrm{C}_{n} \mathrm{H}_{2 n-5} \mathrm{COOH}$, with three double bonds or ethylene groups in the molecule. This acid in the form of triglyceride forms fifteen per cent of linseed oil, while its isomer, iso-linolenic acid forms sixty-five per cent of the oll. It was first found by Hazura $_{38}$ It gives a crystalline hexa-bromide derivative. The two isomeric acids are cal led alphaand betalinolenic acids. Erdmann and Bedford 39 did the first work on these 1solerides. Linolenic acid absorbs oxygen from the air very rapidly, acrolein beinggiven off 40 Oxygen is absorbed much faster by Iinolenic acid than by linolic, and on the percentage composition, with respect to linolenic acid, depends the rate of oxidation of linseed oil. Therefore, the higher the per cent of linolenic acid the higher the rate of oxidation.

With alrakine permanganate linolenic acid gives two hexa-hydroxy acids, known as linusic and 
1so-linusic acids $\mathbf{s}_{34}$

Goldsobel first established the position of the double bonds 37,41 He oxidized it with alkaline permanganate.

$\mathrm{CH}_{3} \mathrm{CH}_{3} \mathrm{CH}=\mathrm{CHCH}_{2} \mathrm{CH}=\mathrm{CHCH}_{2} \mathrm{CH}=\mathrm{CH}\left(\mathrm{CH}_{2}\right)_{7} \mathrm{COOH}==\mathrm{C}_{3} \mathrm{H}_{5} \mathrm{CHO}$ Inolenic acid propaldehyde

$+\mathrm{HOOCCH}_{3} \mathrm{COOH}+\mathrm{CHOCH}_{3} \mathrm{CHO}+\mathrm{HOOC}\left(\mathrm{CH}_{3}\right)_{7} \mathrm{COOH}$ malonic acid

$$
\begin{aligned}
& \text { malonic di- azelaic acid } \\
& \text { aldehyde }
\end{aligned}
$$

Erdmann and Raspe later confirmed Goldsobel's formula 48 but Rollett has since shown that these are only isomoric oxidation products and Rollett claims that this does not in any way show the presence of two different acids in linseed oil.

Like all fatty acid glycerides, linseed oil reacts with alkall to form a soap and free glycerine.

$$
\mathrm{C}_{3} \mathrm{H}_{5}\left(\mathrm{C}_{17} \mathrm{H}_{3}, \mathrm{COO}\right)_{3}+3 \mathrm{KOH}==3 \mathrm{C}_{17} \mathrm{H}_{3}, \mathrm{COOK}+\mathrm{C}_{3} \mathrm{H}_{5}(\mathrm{OH})_{3}
$$

This reaction is taken advantage of in the determination of the aaponification number, and of the unsaponifiable matter. Lewkovitsch even succeeded in hydrolyzing the oil to a remarkable degree in eight hours when he subjected it to steam, with no alkali present.

Hydrogen has no effect on the oll under ordinery 
conditions, but when a catalyst, such as nickel, platinum, or palladium are used the hydrogen gas is absorbed quite readily by the oil, the unsaturated radlcles being saturated by the entering hydrogen. Iodine is slowly absorbed by IInseed oil If a solution of lodine and mercuric chloride in alcbhol is added to the ofl dissolved in chloroform or carbon tetrachloride. The reaction is thought to occur in the following manner, one atom of chlorine and one of iodine attaching to each double bond 4

$$
\begin{aligned}
& \mathrm{HgCl}_{2}+2 \mathrm{I}_{8}=\mathrm{HgI}_{8}+2 \mathrm{ICl} \\
& \mathrm{ICl}+\mathrm{H}_{\mathbf{2}} \mathrm{O}=\mathrm{HCI}+\mathrm{HIO} \\
& \mathrm{C}_{17} \mathrm{H}_{33} \mathrm{COOH}+\mathrm{HIO}=\mathrm{C}_{17} \mathrm{H}_{33} \mathrm{I}(\mathrm{OH}) \mathrm{COOH} \\
& \mathrm{C}_{17} \mathrm{H}_{33} \mathrm{I}(\mathrm{OH}) \mathrm{COOH}+\mathrm{HCl}=\mathrm{C}_{17} \mathrm{H}_{33} \mathrm{IClCOOH}+\mathrm{H}_{2} \mathrm{O} \\
& \mathrm{C}_{17} \mathrm{H}_{33} \mathrm{IClCOOH} \quad==\mathrm{C}_{17} \mathrm{H}_{33} \mathrm{ICOOH}+\mathrm{HCl}
\end{aligned}
$$

Linseed oil readily absorbs ozone at low temperatures, on molecule of ozone being added to each double bond. These ozonides are believed to have the following structure:

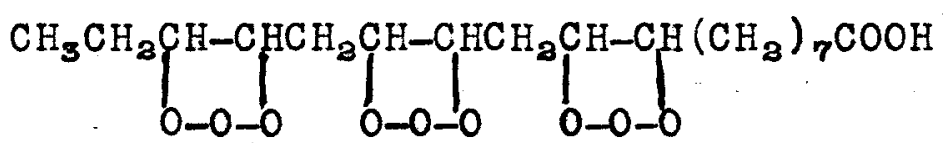

When linseed oil is exposed to the air it gradually absorbs oxygen, yielding an elastic rubberish solid mass, called linoxyn. Mulder, a Dutch chem1st, in 1867, was the first man to get any definite 
results on the oxidation of linseed o1l. From his investigations of different drying oils he drew the following conclusions :

The important constituent of linseed oil is Innolein, $\mathrm{C}_{3} \mathrm{H}_{5} \mathrm{O}_{3}\left(\mathrm{C}_{33} \mathrm{H}_{37} \mathrm{O}_{3}\right)_{3}$, composed of linoleic acid, $\mathrm{HOC}_{32} \mathrm{H}_{27} \mathrm{O}_{3}$, set free by saponification.

The principal substances produced by the drying of linseed oil were thought by Nulder to be linoleic anhydriee, a slimy substance, like India

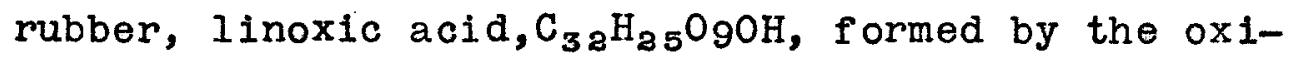
dation of linoleic acid, Iinoxyn, $\mathrm{C}_{3 a^{3}} \mathrm{H}_{27} \mathrm{O}_{1}$, , transformed by alkali into linoxid acid.

Hazura and Bauer worked on hempseed oil, obtaining hempolic acid. This acid is of the series $\mathrm{C}_{n} \mathrm{H}_{2 n-4} \mathrm{O}_{8}$, and according to this anal ys is it has the same composition as linolic ac1d, $\mathrm{C}_{18} \mathrm{H}_{33} \mathrm{O}_{3}$. Sunflower oll, also, consists of glycerides of linolic and oleic acids, with the latter in very small proportions, so that the oll is very suitable for study of linolic acid. Hazura and Bauer took up the work where Mulder left it and discovered that linolelc acid is a misture of four different fatty acids, eighty per cent linolenic acid, together with isolinolenic, linolic, and oleic acids. Hazura stated that "the acids of drying oils 
all behave toward the oxygen of the air in a similar manner $_{45}$ time of drying depending on the proportion of linolic acid to linolenic acid". Linolenic acidis the more unsaturated acid; therefore the higher percentage of linolenic the more rapld the rate of dryIng.

Mulder divided the drying of linseed ofl into two periods:first, when the solid linoxyn was formed, when the oil dries but is elastic, and second, linoxyn is changed to a compound with more oxygen, but the layer becomes brittle and breaks.

He found that the oil when spread in thin layers attained a maximum in several days. The oil was found to increase in weight on drying, due to the absorption of oxygen. This absorption is due to two things: the aboorption of oxygen by substances such as manganese borate in the oil, and the actual absorption of oxygen from the oxides, added as driers.

Weger and Lippert continued liulder's work on the drying power. They of course, did not get $a b-$ solute results, for temperature, light, thickness of the film, alr, etc. effect the drying of the oll, but the results which they obtained were the average of a whole series of experiments carried out under conditions 
as similar as they could obtain. Weger weighed the fllms, spread on pleces of glass, at different times during the period of oxidation. He found that the greatest weight occurred just at the time when the layer did not adhere to the finger when it is pressed lightly. He found that oxidation did not stop at this point, but merely that the oil did not increase in weight beyond that point, that is, atter two to twentyfour hours. This he attributed to the fact that the amount of volatile products given off, carbon dioxide and water, corresponded to the oxygen absorbed. Weger got a maximum increase in weight, varying between 16.8 per cent to 19.9 per cent of the total weight of the oil. This was not found to be the case with boiled o11. The rate of absorbing the oxygen was higher, with boiled oil, that is, it dried better and faster, but the total amount absorbed was the same.

Hal phen studied the work of Mulder and of Hazura and Bauer and drew the following conclusions:

1. The acids of the drying olls behave in the same manner as the glycerides.

2. The oxygen absorbed saturates the unsaturated bonds and also causes the formation of alcohollo products. 
3. The products of oxidation are solid substances, insoluble in ether, which with alkali give compounds soluble in ether. Halphen was unable to tell whether the anhydrides are formed by condensation of two molecules with the elimination of water or by the elimination of water between the carboxyl group and a peroxide group of the same molecule.

4. Linolic and linolenic acids are the ones which take part in the oxidation. Oleic acid forme no solid products, and has no part in the reaction.

5. The oxidation begins on the glycerin, the part combined with oleic, palmitic and myristic acids.

Livache also worked on the oxidation, and got very accurate results. He tested the oll with substances that would increase the 1r drying properties. He exposed the films for two years, analyzing the sample for increase in weight and per cent of insoluble acids. He found that the drying oils are changed to solid substances and that the non-drying oils approach certain of the drying oils. The principal factors influencing the drying of an oll are, according to L1vache, 
1. Degree of purity of the oil.

2. Time elapsed since extraction of the oil from the seed.

3. Manner in which the oll has been stored.

4. Temperature at which the oxidation takes place.

5. Addition of drier, and type and amount of dirier used.

The influence of light on the drying of lin-

seed oil was first studied by Cloes, who passed light through colorless, blue, red, green and yellow glasses. He found oxidation most rapid under colorless glass a nd least rapid under yellow glass.

Moisture seems to have little effect on the drying of linseed oil, according to most authorities, but De Waele 47 bays that it causes the hydrolysis of peroxides during the latter part of oxidation.

If linseed oil is poured on cottonwool and allowed to oxidize a great deal of heat is set free, enough to cause a spontaneous combustion. This is due to the heat of exidation, and depends on the rate of oxidation of the oil, bolled oil rising to a higher temperature than raw oil.

A great deal of work has been done on the percentage composition oflinseed oil. Mulder was the first to work on this and his results 47 were as follows: 


$\begin{array}{lr}\text { Unsaponifiable matter } & 1.00 \% \\ \text { Saturated acids } & 9.40 \% \\ \text { Oleic acid } & 9.40 \% \\ \text { Linoleic acid } & 75.80 \% \\ \text { Glycerol radicle } & 4.30 \% \\ \text { Total } & -100.00 \%\end{array}$

Hazura next worked on the proportions and found the unsaturated acids to be 48

$\begin{array}{lr}\text { Oleic acid } & 5.00 \% \\ \text { Linolic acid } & 15.00 \% \\ \text { Linolenic acid } & 15.00 \% \\ \text { Iso-linolenic acid } & 65.00 \% \\ & \\ \text { Total } & 100.00 \%\end{array}$

According to Hazura's figures, the percentage composition of the oil would then be,
Unsaponifiable matter
$1.00 \%$
Saturated ofganic acids
$8.60 \%$
Oleic acid
$4.30 \%$
Linolic $x$ id
$12.90 \%$
Linoleníc acid $68.90 \%$
Glycerol radicle
$4.30 \%$
Total
$100.00 \%$
Fahrion, in 1910, after carefully study- 
Ing all the data the available, concluded that the average composition was,

$\begin{array}{lr}\text { Unsaponifiable matter } & 0.60 \% \\ \text { Saturated organic acids } & 9.30 \% \\ \text { Oleic acid } & 17.50 \% \\ \text { Linolic acid } & 30.00 \% \\ \text { Linolenic acid } & 38.00 \% \\ \text { Glycerol radicle } & 4.00 \% \\ \text { Total } & 100.00 \%\end{array}$

When linseed oil dries a tough elastic substance called linoxyn is formed. Its composition has not het been d termined, because of the fact that it does not enter into solution without decomposition. Its cautchouc-like character is due to the large moleculb formed, linseed oll 870, and Iinoxyn 1000, in comparison with the fatty acids, 280. It is absolutely insoluble in water, immediately saponifies with potassium hydroxide. Clöes found in linoxyn fatty acids and an insoluble body. Iivache subjected it to various solvents. He found that at first no action was observed, but on continued action the substance swelled up and the liquid became noticeably colored. When the dried film is ground up a different action was noticed. The mass swelled up and divided into small particles, forming a sort of 
salve. If more solvent is addd the particles divide up and the liquid becomes colored. If the mass is separated from the colored Ilquid and the latter is evaporated it is found that a sticky rubbery substance remains behind, which adheres to the fingers. When the insoluble mass is dried an elastic mass which can be rubbed into particles between the fingers is formed. The author worked on the solubility of linoxyn in varlous solvents. The differences or variations in solubility seem to be due to the amount of unoxidized oll remaining in the film.

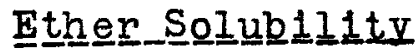

Per cent insoluble

Per cent soluble

Alcohol Solubilility

Per cent insoluble

Per cent soluble
I

65.14

34.78

43.65

56.91

Carbon Disulphide Solubilty

Per cent insoluble

75.06

74.85

74.82

Ber cent soluble

24.82

25.15

28.45

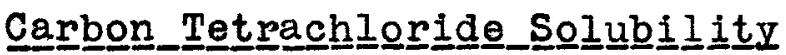

Per cent insoluble

Per cent soluble
65.27

34.77
65.12

64.91

34.82

34.88

Various oxidizing agents were added to lin- 
seed o1l, and the effect noted carefully.

10 cubic centimeters of concentrated nitric

acid were added to 100 cubic centimeters of the oil and the mixture put on a water bath for twenty-four hours. The mixture turned dark immediately and aftrer the mass had been allowed to cool it was found that a solid substance had been formed. This substance was removed from the oily mixture and examined. It was found that it was Iinoxyn, the same substance formed by air oxidation of linsed oil.

Sulphuric acid and potassium dichromato were added to another $\$ 00$ cubic contimeters of oil. The misture immediately turned very dark. No solid substance was formed from this oxidation, however. The effect of hydrogen peroxide was also investigated. 20 cubic centimeters of hydrogen peroxide were added to 50 cubic centimeters of linseed oil. The oil became lighter in color, but showed no oxidation products, showins that hydrogen peroxide is too weak an oxidlzing agent, and merely had a bleaching effect on the oil.

$S_{u l p h u r i c}$ acid and potassium permanganate also caused the oll to turn dark in color. The effect was analogous to that of sulphuric acid and 
potassium dichromate. No solid oxidation product was formed.

Hazura and Bauer ${ }_{\delta}$, stated that the glycerol content of the residue as five per cent of the original weight of Ilnoxyn, while Fahrion found the same results 8

Weger suggested that peroxides are formed during the oxidation of linseed oil. Oleic acid, with one double bond, absorbs no aygen, linolic, with two double bonds, absorbs one molecule of oxygen, and linolentc and isolinolenic, with three, absorbs two molecules of oxygen. Thus the oxidation products are peroxylinolic acid, $\mathrm{C}_{17} \mathrm{H}_{3}, \mathrm{O}_{2} \mathrm{COOH}$, and diperoxyIinolenic acid, $\mathrm{C}_{1}{ }_{7} \mathrm{H}_{29}\left(\mathrm{O}_{3}\right) \cdot{ }_{3} \mathrm{COOH}$. These acids may under$\begin{array}{ll}\text { go several changes, as }\left.\right|_{\mathrm{CH}-\mathrm{O}} ^{\mathrm{CH}-\mathrm{O}}==\prod_{\mathrm{C}=0}^{\mathrm{CH}-\mathrm{OH}} \text {, giving a } \\ \text { hydrozyketoxyacid } & \text { radicle, or }\end{array}$ anoxidized and an unoxidized raticle may combine.<smiles>CCCCC</smiles>

Fahrion believes that linoxyn consists of peroxylinolic, di-peroxy-linolenic acids, partially changed to ketoxy acids 53

Orlopf believes that oxidized bonds are of two types, $\left.\right|_{1} ^{1}$<smiles>[R16]c1ccccc1</smiles> 
Salway believes that the central double bond is unaffected on account of its greater stability, and that a dioxygenide is formed. This, he thinks, yields aldehydes which polymerize to form linoxyn, a small quantity of carbon monoxide and carbon dioxide, and acrolein being evolved at the same time 40

Fahrionse gave as his theory as to the oxidation of fatty acids the following: unsaturated acids with one double bond on oxidation give only volatile products, fatty acids with several leave one intact, add oxygen to the others, and absorb somentra oxygen to form hydroxyl groups, giving hydroxy-acids, insoluble in petroleum ether, soluble in alcohol and in benzane. Fahrion's work has not, however, been proven, as yot and the evidence is not sufficient to establish his theory as fact. The question is still under discussion. Other theories have been a dvanced, but none give conclusive enough evidence to draw a conclusion at the present time. 


\section{Bibligraphy}

1 Ennis, Linseed 011 and Other Seed 0ils, pg.177-8

2 Ibid

3 Toch, Chemistry and Technology of Paints.

4 Andes, Drying Oils, Boiled O\$Is, etc. pg.125

5 Ibid, pg. 131

6 Ibid, pg. 137

7 Eisenschyml, Journal Ind. and Chem. Eng. Jan. 1910

8 Niegemann, Chem. Zeitung, 29, 465, 1905

9 Bllmer and Winter, Lewokvitsch, Chem. Tech. and Analysis of O1ls, Fats and Waxes

10 C. A. Klein, Allen's Commercial Organic Analysis, Vol. II, pg. 340

11 Lewkovitsch, Chemical Technology and Analysis of Oils, Fats and Waxes, Vol. III, pg. 203

12 Ibid, Vol. III, pg. 204

13 Ibid, Vol. I, pg. 461

14 Allen's Commercial Organic Analysis, Vol. II, pg 342

15 Holley, Paint Vehicles, Japans and Varnishes

16 Bulletin 107, 1908, Dept. of Agriculture, Bureaus of Chemistry, pg 142

17 Ibid, pgs. 137, 138

18 Boemer, Nibbelobde, Handbuch der Öle und Fette, pgs. 261, 262 
19 Bulletin 107, 1908, Dept. of Agrlculture, Bureau of Chemistry, pg. 136

20 Williams, Analyst, 1898, 23, pg 253

21 Hazura and Bauer, Allen's Commercial Organic Analysts, Vol.II, pg. 330

22 Haller, Compt. Rend, 1908, 146, pg. 259

23 Morrell, J. Soc. Chem. Ind. 1913, 32, pg. 1091

24 Gmelin, Handbuch der Chemie(Kraut), 1866, 7, pgs. $1230-33$

25 Haller, Compt. Rend., 1908, 146, pg. 259

26 Morrell, J. Soc. Chem. Ind., 1913, 32, pg. 1091

27 Baczewski, Monatsch, 1896, 17, pg. 530

28 Scala, Stz. Sperim. Agri. Ital.1897, 30, pg. 613

29 Canzoniri and Bianchini, Annali Chim. Appl. 1914,

1, pg. 24

30 Wilde and Reychler, Bull. Soc. Chim. 1889, (3), 1, pg. 295

31 Overbeck, Annalen, 1866, 140, pg. 39

32 Haxura, Monatsch., 1887, 8, pg. 260

33 Overbeck, Annalen, 1866, 140, pg. 38

34 Hazura and Brtssner, Monatsch., 1888, 9, pg. 180

35 Peters, Monatsch., 1886, 7, pg. 552

36 Rollett, Zeitsch. Physiol. Chem., 1909, 62, pg. 410

37 Goldsobel, J. Russ. Phys. Chem.Soc., 1906, 38, pg .904 
38 Monatsch, 188\%, 8, pg. 260

39 Erdmann and Balford, Zeitsch. Physiol. Chem. 1911, 74, pg. 179

40 Salway, Trans. Chem. Soc., 1916, 109, pg. 138

41 J. Kuss. Phys. Chem. Soc., 1910, 42, pg. 55

42 Ber., 1909, 42, 1334

43 Zeitsch. Physiol. $\mathrm{C}_{\text {hem. }}$ 1909, 62, pg. 424

44 Wijs-Zeitsch. Angen. Chem., 1898, 11, pg. 291, $1895,18, \mathrm{pg} \cdot 254$

45 Andes, Drying Oils, Boiled Oils, Etc. pg. 7

46 J. Soc. Chem. Eng., 34, 1920, pgs. 48-50

47 Die Chemle der Austrocknenden Oele, Balin, 1867, pgs. 40,48

48 Monatsch. 1876, 8, pg. 260

49 Zeitsch. Angen. Chem., 1910, 23, pg. 722

50 Fel1z Fritz, Kunstoffe, 1919, 9, pgs. 272-3

51 Monatsch. 1888, 9, pg. 459

52 Chem. Umsch. 1920, 27.

53 J. Russ. Physiol. Uhem. Soc., 1910, 42, pg. 658

54 Waele, Chem. World, 1914, 3, pg. 300

55 Ingle, J. Soc. Chem. Ind., 1913, 32, pg. 639

56 Chem. Umschau, 1920, 27, pgs. 158-160, 1921, 28, pgs. $5-7,20-21$ 